\title{
Civilisations
}

Revue internationale d'anthropologie et de sciences

humaines

$54 \mid 2006$

Expériences de recherche en République

démocratique du Congo

\section{Audience-Based Research in the Era of Democratization}

Bob W. White and Yoka Lye

\section{(2) OpenEdition \\ 12 Journals}

Electronic version

URL: http://journals.openedition.org/civilisations/475

DOI: 10.4000/civilisations.475

ISSN: 2032-0442

Publisher

Institut de sociologie de l'Université Libre de Bruxelles

\section{Printed version}

Date of publication: 1 April 2006

Number of pages: 223-232

ISBN: 2-87263-006-6

ISSN: 0009-8140

Electronic reference

Bob W. White and Yoka Lye, "Audience-Based Research in the Era of Democratization ", Civilisations

[Online], 54 | 2006, Online since 01 April 2009, connection on 02 May 2019. URL : http://

journals.openedition.org/civilisations/475; DOI : 10.4000/civilisations.475

(c) Tous droits réservés 


\title{
Audience-Based Research in the Era of Democratization
}

\author{
Bob W. WHITE \& YOKA LYE
}

Summary: As part of a multi-sited international research project (Montreal and Kinshasa) organized around the idea of audience-based research, the "Ethnographies of Listening" research team attempted to go beyond previous studies of the Congolese popular music industry by conducting systematic surveys throughout Kinshasa from June 2002 to August 2005. In the early phases, a large amount of time was spent considering the question of representativeness: how to be sure interviews were conducted in a random and representative manner. Subsequently, the reality of field research and the constraints imposed by limited communication and financial resources led to discussions about the very notion of representativeness and whether or not it was pertinent to the study of popular music. Local and foreign researchers disagreed about the importance of having equal representation in the survey sample and selection of sites. This difference of opinion led to useful discussions about the supposedly inclusive nature of this "collaborative" research project and how its evolution coincided with what some team members referred to as a democratic moment in national politics.

Key words: ethnography, listening surveys, collaborative research, popular music, North-South relations.

Résumé : S'intégrant dans un projet de recherches multi-sites (Montréal, Kinshasa) autour de l'étude d'audience, l'équipe de travail "Ethnographies de l'écoute" a voulu approfondir les précédentes études sur la musique populaire congolaise en menant des enquêtes systématiques à Kinshasa entre juin 2002 et août 2005. Elle s'est longuement penchée, au départ, sur la question de la représentativité : comment s'assurer que les enquêtes soient menées conformément à des modèles aléatoires rencontrant des exigences de représentativité? Les contraintes pratiques du terrain, les difficultés de communication et les limites des ressources financières engagèrent à réfléchir davantage sur la notion de représentativité et sur sa pertinence pour l'étude de la musique populaire. Il s'avéra que les opinions des chercheurs locaux et étrangers divergeaient sur l'opportunité d'avoir des effectifs semblables dans l'échantillon de recherche et dans la sélection des sites. Cette divergence fut à la base de discussions intéressantes sur la nature de la collaboration au sein de ce projet et sur la manière dont son évolution coüncidait, selon certains membres, avec un processus démocratique dans la politique nationale.

Mots-clés : ethnographie, étude de la réception, recherche en collaboration, musique populaire, relations Nord-Sud. 
Tn cultural contexts where listening takes on a fundamentally social character,

popular music represents a field of social practice that is dynamic, interpersonal and highly context dependent. In order to capture this complexity, we must consider how people access meaning through music, and how music is adapted for use in everyday social worlds. Not only do people in Kinshasa use song lyrics to convey messages that would be considered too crude or too direct in spoken form, but they also position themselves in social terms by identifying with particular music groups or genres and distancing themselves from others. As the city that is considered by many to be the capital of modern African dance music, Kinshasa is an ideal location for research on audiences. People in Kinshasa take a great deal of pride in being from Kinshasa (kinois) and they argue that their city has a unique urban culture that cannot be fully grasped without some understanding of the city's music. People often say that Kinshasa and its music "grew up together" (ils ont grandi ensemble). To what extent is it possible to speak of a uniquely urban identity in the Congo? In what ways has this identity changed as Kinshasa went from Kin-la-Belle to Kin-la-Poubelle in less than fifty years? The research discussed in this paper examines the context of listening to popular music in Kinshasa in order to explain how the products of popular culture are linked to urban identity and how the social organization of listening can be used to reflect upon political and economic change since the promises of "democratic transition" in the early 1990s.

\section{Using Audiences to Study Culture}

Audience-based research, still relatively new in the humanities and social sciences, is well suited to studying the complexities of large urban populations characterized by hybridity and mobility (Hecht and Simone 1994). Scholarship on audiences does not exist as a coherent literature, though authors from a variety of disciplines have written on topics that are related in one way or another to the problematic of reception (Barber 1997, Brenneis 1986). This would include literary criticism's interest in readership (Barthes 1975), the attention given to audience in cultural studies (Hall 1993, Radway 1984), and certain semiotic approaches to the study of popular culture and public spectacle (Yoka 2000). Many anthropologists have come to understand (via Volosinov and Bakhtin) that meaning is an outcome of speech and not necessarily something that precedes it, but outside of the rather limited scope of an earlier anthropological literature on the ethnography of speaking (Bauman and Sherzer 1972, Hymes 1974), very little ethnographic research has been done on audiences or on the larger question of how audiences participate in the coproduction of meaning (White 2000).

Recent work on audiences in Africa clearly has the potential to invigorate multidisciplinary research in African Studies (Barber 1997, Jewsiewicki 1996, Meintjes 1990). This new area of inquiry asks important questions about power and the post-colonial state (Fabian 1996, Richards 1996), and it is not reluctant to discuss the products and performances of popular culture that is highly commodified (Jules-Rosette 1992, Larkin 1997, Meyer 2000). Unfortunately most of this research has taken visual forms of cultural expression as its primary object of study, and only rarely has it involved the use of quantitative approaches in ethnographic research. While the growing literature on popular music in Africa often looks at performance and questions of identity in an urban 
setting, it is more concerned with musicians than with audiences (Erlmann 1996, Turino 2000). There has also been a growing interest in the ethnographic study of audiences of various forms of mass media such as television (Abu-Lughod 2005), radio (Spitulnik 1999), mass-media events (Schulz 1999) and advertising (Burke 1996).

Much of this research shows that the meanings associated with popular culture are the result of a complex co-production between artists and their audiences and between audiences themselves. A close examination of how these products are used and what they mean can give access to new ways of imagining political and social life. In many ways, however, the most important contributions of this type of research are methodological. Audience-based ethnographic research shows one way of combining qualitative and quantitative methodologies (since research with audiences depends on relatively large numbers of participants) and through the use of recursive techniques it demonstrates how certain types of ethnographic data can be used to generate additional data for research. The methodologies used in this research emphasize group as well as individual interviews, and the analysis of the data benefits from an approach that is simultaneously text-based and ethnographic.

\section{Research Context and Methodology}

As part of a multi-sited international research initiative organized around the question of audience, the "Ethnographies of Listening" project set out to explore the social organization of music listening in Kinshasa. This project was initiated as a followup to doctoral research conducted by Bob White in 1995-1996 on Kinshasa's popular music industry. While revising his doctoral dissertation for publication, White decided to separate the audience aspect from his original research and to organize a larger more systematic study with a small team of researchers and more varied sources of funding ${ }^{1}$. Lye Yoka was contacted during the grant-writing phase and the two researchers decided to combine their efforts to pool resources and ensure better results. The research team for this project is made up of two units, one in Montreal (under the supervision of White) and one in Kinshasa (under the supervision of Yoka). White began preparations in Montreal in the fall of 2002 and traveled to Kinshasa in the summers of 2003 and 2004 to implement the first two phases of research (individual interviews and group interviews). Following the third phase of research (data analysis), a series of seminars and conferences were held in Kinshasa and various universities in Canada and the US. As the project is still underway, the findings presented in this paper are preliminary.

Research on audiences is demanding, primarily because of the number of participants required to represent the diversity of a given community. The sheer size of such an undertaking makes the prospect of audience-based research daunting to most researchers. In addition to the financial resources needed, the logistics of this type of work requires a large team of researchers to be effective. White came to the project with very particular ideas about the principle of collaborative research, an ideal that has permeated his teaching and fuelled his interest in the politics of representation (White 2002). The idea

1. The authors would like to express their gratitude for funding support from the Social Sciences and Humanities Research Council of Canada (SSHRC), the Fonds Québecois de la Recherche sur la Société et la Culture (FQRSC), and especially the Wenner-Gren Foundation for Anthropological Research (International Collaborative Research Grant Program). 
of collaborative research is one that seemed interesting to Yoka and the other members of the Kinshasa team, though from their perspective it was not a necessary condition for the implementation of the research and in many respects it seemed idealistic and artificially imposed from the outside. The ideological underpinnings of White's notion of collaboration caused some tension in the elaboration of the research methodology but it also provoked a series of discussions about political culture in a time of transition and confusion.

The research was divided into three phases: individual questionnaires, group interviews, and data analysis. Individual questionnaires in the first phase of research were intended to produce information about how people in Kinshasa consume popular music and which songs and artists are perceived as having had the most impact on local audiences. The results of this survey enabled the team to compile a list of approximately 250 songs that could be taken to be representative of popular music since the 1950s. Group interviews were conducted in order to observe the ways that music activates local debates about political culture, morality, male-female relations and generational difference. The third phase of research - data analysis and diffusion of research results - is still in its preliminary stages and should continue until the spring or summer of 2006.

The first phase of the research included a survey questionnaire on individual listening habits and preferences that were administered using random sample techniques in six municipal zones taken to be representative of the city's ethnic and socio-economic diversity. Following the sampling methodology of Schoepf and Engundu (1991), we decided to focus our energies on two relatively poor neighborhoods (Masina and Lingwala), two middleclass neighborhoods (Bandal and Lemba), and two relatively wealthy neighborhoods (Limete and Macampagne). The Personal Listening Survey (PLS) sought three types of information from respondents (see appendix 1): basic socio-economic and demographic data (anonymous and separate from the rest of the survey), specific information about listening and buying habits in relation to various types of Congolese music (popular dance music, religious music and urban traditional music), and a ranking exercise with "hit" songs which were later used to elicit discussion during the group interviews (see appendix 2$)^{2}$. After being tested and modified (initially with the Congolese community in Montreal), the survey was administered to approximately 500 people in Kinshasa, each of whom selected the musical generation that most closely reflected their personal interests and experience (respondents could choose one of four generations or religious music). The PLS was administered by a team of research assistants who underwent a twoday training seminar on sampling, survey methods and elicitation techniques ${ }^{3}$. The PLS included multiple-choice questions, graded ranking questions and open-ended questions. A secondary goal of the survey was to identify potential participants for group interviews, which would take place in the second phase of research.

Participants in the open-ended group interviews of phase two were selected on the basis of their availability (since scheduling of groups posed considerable difficulties)

2. To consult an on-line version of the survey in French, visit http://www.atalaku.net/pages/survey/index. html

3. In alphabetical order, Jean-Claude Diyongo, Jean Liyongo, Henri Mubenga, Leon Tsambu, Emery Mayay, Rigobert Mbila. Serge Makobo, who acted simultaneously as research assistant and project administrator, deserves special mention for his work and investment in the everyday operations of the project. 
but also with an eye toward representativeness within their communities. Homogeneous groups included five to eight people of the same age, gender, or religious beliefs, to the extent that this was possible. Heterogeneous groups had the same number of participants but they were made up of people of mixed social categories (for example a group of men from two different generations or a group of men and women from the same generation). The purpose of homogenous groups was to see if patterns emerge from discussions between people of similar social categories (men and women, young and old, Christian and non-Christian, etc.). Heterogeneous groups enabled researchers to observe the nature of debates that occur between people of different social categories. In some circumstances heterogeneous groups were very lively and productive (for example a mixed group of fans from the third and fourth generation of musicians), but elsewhere this strategy was filled with tension and long, awkward silences (as in the case of one group interview which included practicing and non-practicing Christians).

Group interviews enabled researchers to answer two sets of questions. First, what is the relationship between Kinshasa's long standing tradition of popular music and the city's unique urban identity? Second, what can the study of popular music tell us about social organization and inequality in the Congo's current political and economic crisis? Various experimental research techniques were used for group interviews (personal listening histories, listening and viewing exercises, drawing activities) and an informal interview setting was maintained by conducting interviews in the homes of participants or at common meeting spaces such as restaurants, bars, or community centers. In the final phase of the research, data collected from the PLS and from the group interviews will be analyzed by the principal investigators using discourse analysis and applied semiotics. Written sources such as song lyrics will be combed for recurring phrases, keywords and metaphors, with special attention to statements containing moral claims or value judgments. Oral sources will be transcribed and analyzed in the same way and will also serve as a source of information about the intertextual nature of song lyrics and everyday speech.

\section{Democratization and Popular Music}

In the team's early discussions about research methodology, a considerable amount of time was spent on the question of sampling techniques, namely how to ensure that questionnaires were administered in a way that was both random and representative. But the reality of field research and the constraints imposed by limited time and money led to discussions among the members of the team about the very notion of representativeness and whether or not it was important for the study of popular music, either in Kinshasa or in general. During the team's first meetings in the summer of 2003, White insisted on the importance of administering the surveys to roughly equal numbers of people across various social categories (gender, generation, socio-economic status, and religious affiliation). Respecting this rule, he argued, would ensure that people from all walks of life were allowed to participate in the study and that the results could be said to reflect the diversity of perspectives in Kinshasa. The Congolese members of the team agreed with the importance of elaborating a research strategy that was consistent with methodology in the social and human sciences but some of them had reservations about the application of the sampling technique. There was considerable concern about logistics, which was not surprising given the difficulty of doing research in Kinshasa, a city of more than five 
million people, where poverty and unemployment are endemic and transportation is highly unpredictable. There was a clear preference among the research assistants to interview people considered to be experts on music, not only because they were less numerous, but also because it was thought they would be more motivated to participate. But there were also epistemological concerns with the sampling technique. Several members of the team expressed discomfort with too rigid an application of the methodology on the basis that "Cartesian thinking does not always apply to our African tradition" (Yoka). The exigencies of a systematic approach to sampling were thus perceived of as a guide that should be applied where possible, but not an absolute rule.

An interest in audiences or reception is not common in the Congo, especially because there is a great deal of suspicion surrounding surveys and questionnaires, practices that were often associated with the activities of Mobutu's powerful secret services. The result of this suspicion is an attitude of self-censorship or a tendency toward anecdote. This was certainly the case with the second part of the survey, a series of 29 questions that was supposed to provide supplementary information about the respondent, his or her socio-economic situation, listening habits and family background. During the 2003 team meeting White explained that this part of the questionnaire should only occur at the end of the interview and that the research assistants should reassure respondents that their identity would remain completely anonymous ${ }^{4}$. On more than one occasion, however, several assistants emphasized their dissatisfaction with the 29 questions and Yoka echoed their sentiment. Some of their concerns were addressed in the 2003 meetings before the survey phase began (for example in the wording and order of certain questions, issues that were resolved in some cases thanks to the team in Montreal). Other concerns remained in spite of the modifications to the questions and some were even exacerbated. "This part of the questionnaire was designed for Westerners", said one member of the team after having personally administered nearly 150 questionnaires (Tsambu). It was considered unruly, lengthy and indiscrete, especially in terms of questions pertaining to ethnicity, parents' level of education, and monthly income. There was concern that this part of the questionnaire led to suspicion on the part of respondents, and in some cases assistants changed the order of the questions to address the most sensitive questions last. In certain cases assistants simply dropped those questions that seemed too sensitive. Despite these concerns, certain questions in this part of the survey were considered to be valid for the context of the survey, for example the genre identification exercise (question \#23) or the question that asked for free listing of favorite musicians (question \#24).

In August 2004, after the majority of the surveys had been completed, the data from the approximately 500 interviews was entered into an Excel spreadsheet to facilitate the comparison of results according to different criteria. What resulted was a series of song lists by generation that indicated the relative scores for each of the songs. Using the average score for each generation as a cutoff point, the lists were reduced to approximately 250 titles, spread out over five musical generations. Before showing the results to the other members of the team, White was reluctant to invest too much meaning in the figures, since in many cases the difference between different songs' scores were not statistically significant. Most members of the team agreed that the proximity of certain scores was a

4. For this purpose there was a tear away identity sheet, which was optional, and which served as a means of recontacting those participants interested in future phases of the research project. 
potential problem, but one team member countered by saying that "sometimes numbers matter" (Diyongo). Yoka told a story about how everyone knows the exact percentage of Congo's approximately 5000 university professors who never worked for the Mobutu regime (somewhere less than 5\%) and that this figure had an important impact on the perception of intellectuals. "If we use figures", one assistant said, "then people will respect that". "This is true", said Yoka, "but this can also lead to demagoguery". White interjected saying that in his opinion it would be better to explain the shortcomings and biases inherent in the study and let people judge for themselves the quality or relevance of the findings. "This transparency", he said, "is an important part of the methodology, but we don't necessarily have to present it that way. The question of how we present these findings is very important, and this is the question before us today".

White then asked the other members of the team how they thought the project should be presented, especially given the project's potential to be of interest to the general public: "How is our approach different from a television show that takes callers or a newspaper that publishes letters from readers?" In response to this question there was general agreement on a number of distinguishing characteristics : the international makeup of the research team, a long-term approach to the research question, the systematic nature of the methodology. Then one of the assistants suggested that the research team represented a kind of "all-star" formation (selection nationale) : "What is different about our approach is that as a team we come out of nowhere, we came together specifically for this project and that is reflected in our methodology" (Makobo). He continued in this direction by making a comparison between the research team and Wenge Musica, the flagship group of the fourth musical generation, and one of the most successful musical empires to have broken onto the local music scene outside of the constraints of the leaders of the previous musical generation. "Wenge wanted to do something democratic", explained Makobo, "well, maybe not democratic but definitely not charismatic. They were all equal, they started the band as equals and that was the secret of their success". Yoka argued that there have always been charismatic leaders and White added that there have always been attempts to undo that leadership. They both agreed that the problem occurs when certain members decide to leave the group to establish their charismatic leadership and a sphere of influence (la dislocation). "This is interesting" interjected White, "Does the democratic metaphor work?" There is some silence as the question sinks in. "Maybe it works", offers Yoka, "but the political project is always subverted by someone who wants to split from the group". Immediately one of the assistants jumped in : "What keeps the team together is the common goal, the work. And this is revolutionary, but every revolutionary project is in danger of being subverted. For real change to occur, we have to change the way we think, our attitudes" (Diyongo).

The findings that are emerging from this study suggest that changes in attitude are just as likely to emanate from audiences as they are from musicians; if music has the potential to act upon individuals and audiences, then clearly individuals and audiences can act upon the music, and music in turn can act upon society. A musician who displays morally reprehensible behavior in his private life or in the way that he interacts with other musicians will often be sanctioned in terms of audience loyalty; this observation was confirmed in the ranking of hit songs. For example Papa Wemba and Koffi Olomide, generally recognized as two of the most important and certainly the most internationally recognized artists from Kinshasa, did not do as well in the ranking as the members of the research team would have expected. Audiences can react negatively to popular musicians 
for various reasons: evidence of involvement in illegal or criminal activity (such as Wemba's involvement in an illegal immigration scandal), brutal or violent behavior (for example Koffi's violent outburst following a concert in 2004), the use of witchcraft with malicious intent (White 2004), or the vice of arrogance. The appreciation of musicians' value as artists is intimately linked with their position as moral agents and when this morality is called into question, audiences in Kinshasa tend to vote with their ears. Yoka continued to think through the question of the democratic metaphor:

"Bob, the other day you were talking about democratic resurgence. This is...this is intuitive but it is not totally wrong. You were saying, could this be a kind of democratic intuition? In spite of all the problems [with the Western notion of democracy], I think it might be true. A democratic intuition. People look at musicians and they start to judge them. They say: if you're a thief, we won't listen to you anymore".

This was perhaps the same reasoning that led one participant in a group interview to argue that in popular music there is no corruption, since unlike in the realm of politics, your chances for success have more to do with talent and perseverance than your ethnic affiliation or who you know. But it is also possible that the question of democratization, which was introduced into to the discussion by White, reflects a Western bias and that the other members of the team were simply responding to a new version of a longstanding preoccupation among foreigners working and traveling in the region: responsible leadership.

Due to the limitations of space we have not been able to fully address what happened during the "democratic transition" in the beginning of the 1990s, when Mobutu made tentative gestures toward the path of democratic reform. Nor have we covered in any detail the question of how popular culture is related to politics or political practice, questions that we hope to address in future publications. Despite these limitations, however, we can say that the systematic study of reception, even in a context such as Kinshasa where mass media is generally considered "primitive", can bring to light important information about how the products of popular culture mediate between artists and their audiences. Furthermore, a critical examination of research methodology suggests that audiencebased research uncovers important aspects of the relationship between everyday forms of socialization (such as listening to popular music) and the political imaginary in a particular region. Most importantly for the purposes of this publication, our research suggests that the process of research is itself a terrain for understanding how particular methodological orientations and their corresponding ideologies (especially those coming from scientific traditions in the West) influence the emergence of particular types of research questions and scholarly sociability. 


\section{References}

Abu-Lughod, Lila, 2005. Dramas of Nationhood: The Politics of Television in Egypt. Chicago: The University of Chicago Press.

BARBER, Karin, 1997. "Preliminary Notes on Audiences", Africa, 67 (3), pp. 347-62.

BARTHES, Roland, 1975. The Pleasure of the Text. New York: Hill and Wang.

Bauman, Richard and Joel Sherze, 1972. Explorations in the Ethnography of Speaking. New York: Cambridge University Press.

BRENNEIS, Don, 1986. “Shared Territory: Audience, Indirection and Meaning”, Text, 6 (3).

Burke, Timothy, 1996. Lifebuoy Men, Lux Women: Commodification, Consumption and Cleanliness in Modern Zimbabwe. Durham, NC: Duke University Press.

Erlmann, Veit, 1996. Nightsong: Performance, Power and Practice in South Africa. Chicago: University of Chicago Press.

FABIAn, Johannes, 1996. Remembering the Present: Painting and Popular History in Zaire. Berkeley: University of California Press.

Hall, Stuart, 1993. "Encoding, Decoding”, in Simon During (ed.), The Cultural Studies Reader, pp. 90-103. New York: Routledge.

Hecht, David and Maliqalim Simone, 1994. Invisible Governance: The Art of African Micropolitics. Brooklyn: Autonomedia.

Hymes, Dell, 1974. Foundations in Sociolinguistics: An Ethnographic Approach. Philadelphia: University of Pennsylvania Press.

Jewsiewicki, Bogumil, 1996. "Zairian Popular Painting as Commodity and as Communication”, in Mary J. Arnoldi, Christraud M. Geary, and Kris L. Hardin (eds), African Material Culture. Bloomington: Indiana University Press.

Jules-Rosette, Bennetta, 1992. "What Is 'Popular'? The Relationship Between Zairian Popular and Tourist Paintings”, in Bogumil Jewsiewicki (ed.), Art pictural zairois, pp. 41-62. Sillery, Québec: Editions du Septentrion.

LARKIN, Brian, 1997. "Indian Films and Nigerian Lovers: Media and the Creation of Parallel Modernities", Africa, 67 (3), pp. 406-40.

Mankekar, Purnima, 1999. Screening Culture, Viewing Politics: an Ethnography of Television, Womanhood and Nation in Post-Colonial India. Durham, N.C.: Duke University Press.

Meintjes, Louise, 1990. "Paul Simon's 'Graceland', South Africa, and the Mediation of Musical Meaning”, Ethnomusicology, Winter issue.

Meyer, Birgit, 2000. "Ghanaian Popular Cinema and the Magic in and of Film”, in Birgit Meyer and Peter Pels (eds), Magic and Modernity. Interfaces of Revelation and Concealment. New York: Routledge.

RADWAY, Janice, 1984. "Interpretive Communities and Variable Literacies: The Functions of Romance Reading”, Daedalus, 113 (3), pp. 49-73.

Richards, Paul, 1996. Fighting for the Rain Forest: War, Youth \& Resources in Sierra Leone. Portsmouth, N.H.: Heinemann.

Schoepf, Brooke Grundfest and Walu Engundu, 1991. "Women's Trade and Contributions to Household Budgets in Kinshasa", in Janet MacGaffey (ed.), The Real Economy of Zaire. Philadelphia: University of Pennsylvania Press.

Schulz, Dorothea, 1999. "In Pursuit of Publicity. Talk Radio and the Imagination of a Moral Public in Mali", Africa Spectrum, 99 (2), pp. 161-185. 
Situlnik, Debra, 1999. Producing National Publics: Audience Constructions and Electronic Media in Zambia. Durham, N.C.: Duke University Press.

Turino, Thomas, 2000. Nationalists, Cosmopolitans, and Popular Music in Zimbabwe. Chicago: University of Chicago Press.

White, Bob W.

2000. "Modernity's Trickster: Dipping and 'Throwing' in Congolese Popular Dance Music", Research in African Literatures, 30 (4), pp. 156-175.

2002. "Le cauchemar d'Adorno", L'Autre Forum. Université de Montréal. Fall.

2004. "The Elusive 'Lupemba': Rumors About Fame and (Mis) Fortune in Kinshasa", in Theodore Trefon (ed.), Reinventing Order in the Congo: How people respond to state failure in Kinshasa. London: Zed Books.

YOKA LYE M.

1984. "Radio Trottoir: le discours d'inversion". Ethiopiques, $3^{\mathrm{e}}$ semestre.

1995. Lettres d'un Kinois à l'oncle du village. Paris: L'Harmattan.

2000. Kinshasa, signes de vie. Paris, Bruxelles: CEDAF/L'Harmattan. 


\section{Appendix 1}

\section{Personal Listening Survey}

\section{Instructions}

1. Choisissez une ou deux des quatre périodes ou générations musicales indiquées ci-dessous. Choisissez seulement les générations que vous connaissez le mieux.

$1^{\text {ère }}$ génération : Wendo, Feruzi, Bowane, etc.

$2^{\mathrm{e}}$ génération : Kallé, Franco, Rochereau, etc.

$3^{\text {e }}$ génération : Zaiko Langa Langa, Empire Bakuba, Viva la Musica, etc.

4 e génération : Wenge Musica, Koffi, Félix Wazekwa, etc.

La musique religieuse contemporaine : Denis Ngonde, Makoma, Charles Mombaya

2. Lisez la liste des chansons ci-jointe et donnez votre opinion sur la popularité de chaque chanson.

Par exemple: à partir de la liste qui accompagne ce questionnaire, évaluez les chansons une par une. Pour celles que vous jugez comme faisant partie des dix plus grandes chansons de la musique congolaise, attribuez-leur le chiffre [6] dans la colonne correspondante. De même, attribuez le chiffre [5] pour celles que vous jugez comme faisant partie des 50 plus grandes chansons de la musique congolaise et ainsi de suite, [4] pour les 100 plus grandes, et [3] pour les 500 plus grandes. Indiquez le chiffre [2] pour les chansons qui sont moins connues, soit les 1000 plus grandes chansons. Pour une chanson que vous ne connaissez pas ou qui ne devrait pas faire partie du top 100, indiquez [1].

6. : un très grand succès

5. : un grand succès

4. : un succès

3. : une chanson connue

2. : une chanson plus ou moins connue

1. : une chanson inconnue

Une seule réponse par question, SVP.

Attention: En répondant aux questions, rappelez-vous qu'il s'agit des chansons les plus connues ou populaires, et pas nécessairement de vos chansons préférées. Un tube, c'est une chanson qui est reconnaissable par le plus grand nombre de personnes, indépendamment de l'âge, de la religion, du sexe ou de l'ethnicité. Un tube, c'est une chanson qui a marqué son époque.

Après avoir rempli le questionnaire, répondez à la série de questions relatives à votre situation de vie.

L'objectif de cette partie du questionnaire est de pouvoir comparer les habitudes d'écoute avec votre situation de vie. Il est important de souligner que votre identité restera anonyme.

Ne pas écrire votre nom sur ce formulaire

Date et heure du commencement de l'entrevue :

Lieu de l'entrevue :

Numéro d'entrevue :

Nombre des personnes présentes : 
Répondez aux questions suivantes :

1. Quel âge avez-vous?

2. Quel est votre sexe?

Quelle est votre situation matrimoniale?

Avez-vous des enfants?

3. Où êtes-vous né(e)? (Ville, quartier, pays, combien de temps y êtes-vous resté(e)?)

4. Où avez-vous passé votre enfance?

5. Où avez-vous passé le plus grand nombre d'années de votre enfance?

6. Depuis combien de temps vivez-vous à Kinshasa?

7. Niveau de scolarité :

0 - Primaire :

0 - Secondaire :

0 - Universitaire :

8. Où est né votre père?

Où a-t-il grandi?

Combien d'années de scolarité a-t-il eues?

Quelle est/était son occupation?

Où est née votre mère?

Où a-t-elle grandi?

Combien d'années de scolarité a-t-elle eues?

9. Quelle est votre origine ethnique?

10. Quelle est la langue que vous utilisez le plus à la maison?

11. Quelle est votre occupation principale?

12. a. Quel le minimum qu'il vous faut pour vivre par jour?

b. Y arrivez-vous?

13. Comment faites-vous pour nouer les deux bouts à la fin du mois?

14. Etes-vous membre d'une Eglise? Laquelle?

15. Vos parents sont-ils ou étaient-ils membres d'une Eglise? Laquelle?

16. Combien de fois par semaine assistez-vous à des réunions religieuses (prière, messe, réunion administrative, etc.?

17. Avez-vous déjà voyagé en dehors du Congo?

Si oui, où, quand et pour combien de temps? 
18. Indiquez les biens dont vous êtes propriétaire ou auxquels vous avez accès tous les jours?

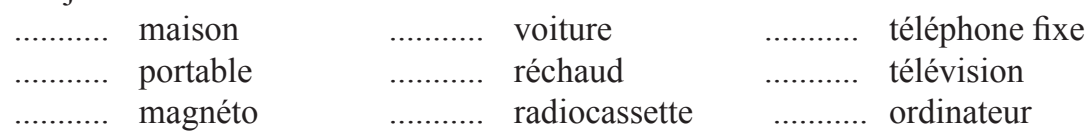

19. Avez-vous des membres de la famille vivant à l'étranger?

20. Vous aident-ils à vivre?

21. Quels types de musiques connaissez-vous?

22. Y en a-t-il que vous n'écoutez pas?

23. Lesquelles écoutez-vous?

\begin{tabular}{l|l|l|l|l|l}
\hline Genre & Jamais & Rarement & Parfois & Souvent & Exclusivement \\
\hline Religieuse & & & & & \\
\hline Folklorique & & & & & \\
\hline Moderne & & & & & \\
\hline Américaine & & & & & \\
\hline Française & & & & & \\
\hline Africaine & & & & & \\
\hline Reggae & & & & & \\
\hline Rap & & & & & \\
\hline World music & & & & & \\
\hline Classique & & & & & \\
\hline Jazz & & & & & \\
\hline Country & & & & & \\
\hline Techno & & & & & \\
\hline Autres & & & & & \\
\hline
\end{tabular}

24. Citez par ordre les artistes que vous avez l'habitude d'écouter :

25. Comment vous procurez-vous la musique (achat, prêt, etc.) :
a. Achetez-vous les K7 ou les CD?
b. Evaluez la fréquence d'achat (rarement, parfois, souvent, toujours)

26. Combien payez-vous un $\mathrm{CD}$, une $\mathrm{K} 7$ ?

27. Combien de $\mathrm{K} 7 / \mathrm{CD}$ achetez-vous par mois?

$\mathrm{K} 7$ : $\mathrm{CD}$ : 
28. Combien de K7/CD avez-vous?

K7 : $\mathrm{CD}$ :

29. Assistez-vous à des concerts?

a. Quel genre?

b. Combien de fois par mois?

c. Combien d'argent dépensez-vous par concert?

Si vous êtes intéressé(e) à participer à la deuxième phase de cette étude, veuillez détacher et remplir la feuille suivante.

Nous vous remercions vivement de votre participation et nous vous invitons à consulter le site $\underline{w w w . a t a l a k u . n e t}$ pour suivre de près l'évolution des recherches.

Heure de fin de l'entrevue :

Durée totale de l'entrevue en minutes :

Veuillez détacher cette feuille SVP

Pour en savoir plus sur ce projet de recherche, veuillez détacher et remplir cette feuille qui doit être remise séparément avec le questionnaire.

'Oui, j'aimerais en savoir plus de votre projet de recherche'

Nom :

Numéro de téléphone :

Adresse :

Le meilleur moment pour vous joindre :

Je connais quelqu'un d'autre qui pourrait également s'intéresser au projet :

Nom :

Téléphone : 